\title{
Effect of Chestnut and Acorn Flour on Wheat / Wheat-Barley Flour Properties and Bread Quality
}

\author{
Marie HrušKováa ${ }^{a}$ IVAn Švec ${ }^{a^{*}}$, AND IVAna KadLČÍKOvÁa \\ ${ }^{\text {a }}$ Department of Carbohydrates and Cereals, University of Chemistry and Technology Prague \\ ${ }^{*}$ Corresponding author \\ Ivan.Svec@vscht.cz \\ TEL: +420220443206
}

Received: 12 December 2017; Published online: 18 April 2019

\begin{abstract}
Additions of barley flour alone or with combination of chestnut and acorn flour $(30 \% ; 30+5 \%$; $30+10 \%)$ were aimed at increasing the dietary fibre content in wheat bread. In this regard, enhancement by acorn flour elevated the dietary fibre by a greater extent (up to 7.80\%) compared to barley or chestnut flours. Increasing the proportion of non-traditional raw materials also influenced flour pasting properties during the amylograph test as well as the farinograph and extensigraph properties of nonfermented dough. In contrast to the wheat flour, analysis of Falling Number and Zeleny values showed a decrease in technological potential of flour composites of approximately $30 \%$. Water absorption increased about 2 percentage points, mainly with enhancement by chestnut flour. All the non-traditional raw materials slowed dough development, whilst dough softening degree differed according to actual composition. Dough viscous and elastic properties worsened as shown by a decrease of in energy absorbed, depending on the type and the addition of the non-traditional products. Changes in flour composition were reflected in amylograph viscosity maximum, which became lower with increasing amounnts of chestnt and acorn flour. A significant worsening of the bread specific volume as well as of bread shape (vaulting) corresponded with a partial dilution of the gluten matrix. Compared to the wheat bread, $10 \%$ chestnut flour caused bread size to diminish to less than one half of the wheat loaf. Statistically, the principal features were water absorption, dough softening degree and extensigraph energy together with specific bread volume. In terms of wheat flour and bread quality, the influence of barley flour overcame the effects of adding chestnut or acorn flours.
\end{abstract}

Keywords: Wheat-barley composite flour; Chestnut flour; Acorn flour; Bread; Principal component analysis

\section{Introduction}

For hundreds of years, fine wheat flour represented a "white gold", accessible for the richer minority of society. Owing to this, plebeian nutrition was based on rye or barley together with legumes and pseudocereals. In this regard, edible fruits from trees were rarely used, and served primarily as a feed for domestic animals. Nevertheless, in times of crop failure caused e.g. by flooding or local wars, humans gratefully ate plant

Copyright (C)2019 ISEKI-Food Association (IFA) products such as chestnut or acorn to stay alive. Later, the industrial revolution supressed social discrepancies and wheat flour gradually became the basic raw material for nearly all social classes. Alternative plant raw materials have been forgotten, and only with the rising incidence of lifestyle diseases have we returned to their intentional consumption.

Chestnuts, fruits of tree Castanea sativa Mill., are traditionally treated by hydrothermal pro- 
cess to transform them into flour. Compared to wheat, chestnut flour contains much more simple sugars and dietary fibre (ca $2 \%$ vs. $16 \%$ and $2 \%$ vs. $26 \%$, respectively), but approximately a half protein content (6\% against 10-15\%; Giovannelli (2009) and CREA (2015a, 2015b) respectively). In limited amounts, chestnut flour alone or in combination with rice flour may improve volume of biscuits (Hegazy, Kamil, Hussein, \& Bareh, 2014) or gluten-free bread (Demirkesen, Mert, Sumnu, \& Sahin, 2010).

Acorns are fruits from several species of oak tree, especially holm oak Quercus rotundifolia or $Q$. ilex. To produce acorn flour, fruits traditionally undergo drying or roasting, peeling and milling. A further step may be flour debittering, i.e. tannins extraction. The nutrition characteristics of this naturally gluten-free flour are mentioned by Silva et al. (2016): half the protein content (4-5\%), ten-times higher fat content (10$14 \%$ ) and around seven-times higher dietary fibre level (13-17\%) compared to wheat flour. Pasting properties of acorn starch differ from that from chestnut - on viscograph curves, no peak and trough points were identified during slurry heating and holding at a higher constant temperature. The viscosity in 40th min of the test was about approximately one-third lower just for acorn flour (900 vs. 1300 Brabender units; Correia and Beirao-da-Costa (2010)). In Sardinia, acorn bread was part of local folklore and its preparation was a ceremony with religious connotations (Pinna, 2013).

Korus, Witczak, Ziobro, and Juszczak (2015) found that only the lowest (20\%) replacement of corn and potato starches in gluten-free bread recipe led to a rise in the final product volume. When $50 \%$ wheat flour was replaced by acorn meal, composite cookies differed from control in texture, appearance, and flavour slightly; they were still considered as acceptable (Sabrin, 2009).

Barley (Avena sativa L.), is the one of the basic cereals, i.e. plants bred for human nutrition for the longest time; in ancient Egypt, emmer wheat and barley served for bread and beer production (Samuel, 1997). In barley flour, protein content is usually around $10 \%$, forming a lower portion than in wheat flour, and but the reverse is true for the polysaccharides (close to
80\%). A substantial part of the biopolymers in the latter form $\beta$-glucans and arabinoxylans - Belcredi, Ehrenbergerova, Belakova, and Vaculova (2009) analysed 12 different samples, and determined level of both components to be between $2.78-6.08 \%$ and $3.66-5.46 \%$, respectively. These polysaccharides may help in prevention of lifestyle diseases - the European Commission approved health claims for barley and oat $\beta$ glucans (EFSA, 2011). Within the Czech Republic, barley flour found its fixed place among bakery raw materials, and together with e.g. chia and nopal flour, it extended the range of bread types produced. As reported Gill, Vasanthan, Ooraikul, and Rossnagal (2002), quality of wheat-barley bread depends also on barley type (regular, waxy). For 15\% substitution of wheat flour by regular barley one, bread loaf volume was larger and crumb softer than for counterpart containing waxy barley flour. Similarly, the molar mass of barley $\beta$-glucans predetermines the resulting bread properties. In terms of increasing the specific bread volume and reducing the crumb firmness, addition of $\beta$-glucans characterised by molar masses of $2.03 \times 10^{5}$ and $1.00 \mathrm{x}$ $10^{5}$ resulted in preference of the loaves made with the higher mass $\beta$-glucans (Skendi, Biliaderis, Papageorgiou, \& Izydorczyk, 2010). These authors mentioned that $0.6 \%$ of such $\beta$-glucan type improved rheological properties of wheat dough as shown by prolongation of both farinograph dough development and stability during kneading. With respect to dough machinability, $\beta$ glucans supported dough extensigraph elasticity: elasticity-to-extensibility ratio increased almost twice $(0.52$ for weak bakery wheat control 'Dion', and 0.95 for that composite dough). The rise in dough elasticity alleviates the expansion of pores in dough during fermentation and thereby it increases bread crumb softness (compressibility). The aim of this work was to evaluate basic analytics, viscous and elastic behaviour of wheat or wheat-barley flour composites containing two different amounts of chestnut or acorn flour. Baking potential of the flour composites prepared was evaluated directly in a laboratory baking trial. To distinguish the influence of the nontraditional plant material types and dosage levels, results were statistically analysed by principal components.

IJFS | April 2019 | Volume 8 | pages 41-57 


\section{Materials and Methods}

\subsection{Wheat and barley flour}

Two samples of white wheat flour (WF1 and WF2), used as a bases for bi- and tri-composite blends, were produced by the Czech commercial mill Delta Prague in years 2015 and 2016. They were characterised by protein contents of $11.2 \%$ and $13.2 \%$, Zeleny values of 50 and $39 \mathrm{~mL}$ and Falling Number values of 341 and 432 s, respectively. Barley flour (BF) was supplied by the Czech commercial mill Křesín (production year 2015), and was described by protein content, Zeleny value and Falling number as $9.23 \%$, $23 \mathrm{~mL}$ and $119 \mathrm{~s}$, respectively. Total dietary fibre (TDF) ratios were similar $(3.40,3.18$, and $4.25 \%$ for WF1, WF2 and BF, respectively; Table 1). In the cereal premixes WF1BF and WF2BF, barley flour replaced $30 \%$ of WF1 or WF2 (mixing ratio $30: 70 \mathrm{w} / \mathrm{w}$, respectively).

\section{$2.2 \quad$ Non-traditional flour samples}

Further non-traditional plant materials, namely chestnut (C) and acorn (A) flour, were bought in local specialised food shops. The former was produced by Sonnentor Kräuterhandelsgesellschaft $\mathrm{mbH}$ (Austria) and the latter was from Bioobchod, Czech Republic (agriculture production EU mentioned on a label). Declared protein contents were $4.9 \%$ and $4.1 \%$, respectively. Ratio of TDF was determined analytically as $13.52 \%$ and $44.49 \%$, respectively. Replacement levels of both wheat flour and wheat-barley premix were chosen as 5 or 10 wt. \% (coding e.g. WF $1+5 \mathrm{C}$, $\mathrm{WF} 2+10 \mathrm{~A}, \mathrm{WF} 1 \mathrm{BF}+5 \mathrm{~A})$.

\subsection{Analytical tests}

Analytical testing of wheat controls and prepared flour composites consisted of the technological parameters Falling number (ISO 3039) and Zeleny sedimentation value (ISO 5529), determined in two replications each. In correspondence to EU legislation (Regulation 1169/2011), TDF was calculated from data for pure flour samples (wheat, barley, chestnut and acorn flour; AOAC method 991.43). Due to method repeata- bility determined earlier (actual standard deviation 0.22 percent points), it was possible to carry out the measurement with a single repetition.

\subsection{Rheological behaviour}

Viscous behaviour was determined according to ICC method No 126/1, using the Brander Amylograph (Germany) (80 g of solids, $450 \mathrm{~mL}$ of distilled water). Rheological characteristics of wheat and composite non-fermented dough were recorded using the Farinograph and the Extensigraph (Brabender Germany; ISO 5530-1:2013 and ISO 5530-2:2013, respectively). Due to preparation of leavened bread, whose proofing takes $50 \mathrm{~min}$, only the Extensigraph data after $60 \mathrm{~min}$ of dough resting was considered.

\subsection{Bread baking trial}

Bread preparation and assessment of its characteristics were carried out as described in previous work (Švec \& Hrušková, 2004). Leavened dough was prepared using the Farinograph, with the basic formula: $300.0 \mathrm{~g}$ wheat flour, $12.0 \mathrm{~g}$ yeast, 5.1 $\mathrm{g}$ salt, $4.5 \mathrm{~g}$ sugar, $3.0 \mathrm{~g}$ margarine and sufficient distilled water needed for preparation of dough to a consistency of $600 \pm 20$ Brabender units (consistency based on experience of the Research Institute of Milling-Baking Industry, Czech Republic). Recipe water additions were determined to be in the range $53.5 \%-62.5 \%$ on basis of flour weight, i.e. from $160.5 \mathrm{~mL}$ to $187.5 \mathrm{~mL}$. In the evaluation of flour composites, wheat flour was replaced by wheat-chestnut/acorn blends, wheatbarley premix, or wheat-barley-chestnut/acorn mixture. Commercial French-type yeast "Fala" and the Czech margarine "Perla" (fat content $40 \%$ ) were used (producers Lesaffre Czech Republic and Unilever Czech Republic, respectively). Dough fermentation and leavening took 50 and $45 \mathrm{~min}$ at constant temperature $\left(30{ }^{\circ} \mathrm{C}\right.$, RH 95\%); 70 g dough pieces were moulded manually, then placed on a baking plate. Baking for 14 min was performed in a laboratory oven (Bakery Research Institute, Poland) preheated to 240 ${ }^{o} \mathrm{C}$; steamed was created immediately after full baking plate insertion by injection $50 \mathrm{~mL}$ of distilled water. After two-hour cooling under lab- 
Table 1: Barley, chestnut and acorn flour influence on polysaccharide pasting properties

\begin{tabular}{|c|c|c|c|c|}
\hline \multirow[b]{2}{*}{ Flour, flour composite } & \multicolumn{2}{|c|}{ Analytics } & \multicolumn{2}{|c|}{ Amylograph test } \\
\hline & $\begin{array}{l}\text { TFD } \\
(\%)\end{array}$ & $\begin{array}{c}\text { Falling } \\
\text { number } \\
(\mathrm{s})\end{array}$ & $\begin{array}{l}\text { Temperature } \\
\text { of maximum } \\
\left({ }^{o} \mathrm{C}\right)\end{array}$ & $\begin{array}{c}\text { Viscosity } \\
\text { maximum } \\
(\mathrm{BU})\end{array}$ \\
\hline WF1 & 3.40 & 341 de & $85.0 \mathrm{~cd}$ & $460 \quad \mathrm{c}$ \\
\hline WF2 & 3.18 & $420 \mathrm{f}$ & $88.4 \mathrm{de}$ & $940 \quad \mathrm{~d}$ \\
\hline $\mathrm{BF}$ & 4.25 & $107 \quad \mathrm{a}$ & n.d. & n.d. \\
\hline WF1BF & 3.72 & $304 \quad \mathrm{c}$ & $79.0 \quad \mathrm{~b}$ & $355 \quad \mathrm{c}$ \\
\hline WF2BF & 3.50 & $168 \mathrm{ab}$ & $69.0 \quad \mathrm{a}$ & $215 \quad a b$ \\
\hline $\mathrm{WF} 1+5 \mathrm{C}$ & 3.91 & $323 \mathrm{~cd}$ & $85.8 \mathrm{~cd}$ & $415 \quad \mathrm{c}$ \\
\hline $\mathrm{WF} 1+10 \mathrm{C}$ & 4.41 & $317 \quad \mathrm{~cd}$ & 88.0 de & 420 \\
\hline $\mathrm{WF} 2+5 \mathrm{~A}$ & 5.23 & $408 \mathrm{f}$ & 96.0 & $>1000$ \\
\hline $\mathrm{WF} 2+10 \mathrm{~A}$ & 7.29 & 388 ef & 91.0 ef & $>1000 \quad \mathrm{~d}$ \\
\hline $\mathrm{WF} 1 \mathrm{BF}+5 \mathrm{C}$ & 4.21 & $286 \quad \mathrm{c}$ & $82.0 \quad \mathrm{bc}$ & 345 \\
\hline $\mathrm{WF} 1 \mathrm{BF}+10 \mathrm{C}$ & 4.70 & $276 \quad \mathrm{c}$ & $82.0 \mathrm{bc}$ & $360 \quad \mathrm{c}$ \\
\hline $\mathrm{WF} 2 \mathrm{BF}+5 \mathrm{~A}$ & 5.54 & $178 \mathrm{ab}$ & $70.0 \quad \mathrm{a}$ & $190 \quad \mathrm{a}$ \\
\hline $\mathrm{WF} 2 \mathrm{BF}+10 \mathrm{~A}$ & 7.58 & $185 \mathrm{~b}$ & 72.0 & $185 \quad \mathrm{a}$ \\
\hline Repeatability & 0.22 & 25 & 0.20 & $4.20 \%$ \\
\hline $\begin{array}{l}\text { Number of groups } \\
\text { (of total) }\end{array}$ & n.d. & $6 / 12 \quad(a-1)$ & $6 / 12 \quad(a-1)$ & $4 / 12 \quad(a-1)$ \\
\hline Distinguishing rate & n.d. & $50 \%$ & $50 \%$ & $33 \%$ \\
\hline
\end{tabular}

TDF - total dietary fibre content, feature excluded from ANOVA (calculated, i.e. dependent values for flour composites tested); n.d. - not determined.

WF - Wheat flour; WF1BF, WF2BF - wheat-barley flour premix 70:30 wt. \%, respectively; BF, A, C - barley, acorn and chestnut flour, WF - Whe respectively

a-f - means in columns with the same letter were not statistically different $(\mathrm{p}>0.05)$

Number of groups - number of homogenous groups, statistically differing in their averages, identified by different letters (a-f).

Total number of groups - number of tested samples ( $\mathrm{N}=12$; corresponding letters a-1).

Distinguishing rate $(\%)=100$ Number of homogenous groups/Total number of groups $(=12)$

oratory conditions, the specific volume and the shape (height-to-diameter ratio) was determined in triplicate. To measure the volume of buns, the traditional volume displacement method with rapeseeds was used. For crumb firmness (or softness) evaluation, gravitational penetrometer PNR-10 (Petrotest Instruments, Germany) was employed. This apparatus was equipped with a stainless steel hemisphere (25 $\mathrm{mm}$ diameter), locked in a metal screw holder (total weight 150 g). Crumb samples were cut out of the centre of the bun halves (height and diameter of crumb cylinders $35 \mathrm{~mm}$ and $30 \mathrm{~mm}$ ), and the penetration depth was determined after a compression time of $5 \mathrm{~s}$ (five replications for each sample). In eight-point sensory analysis, three skilled assessors were employed, thus results of the test have informative character only. On a hedonic scale, summary sensory profile could reach values from 8 to 24 points as the best and the unacceptable bread, respectively (the higher score, the higher extent of negative changes). Quality attributes evaluated were: bun shape (vaulting), crust colour and shine, crust thickness and crispness, crumb elasticity and porosity, aroma and taste, crumb chewiness, and stickiness to palate. For single parameters, bread quality was classified into three categories: 1 - optimal, typical; 2 - acceptable (soft) change, non-typical, flat; 3 - unacceptable, strange (negative, unfavourable change). Within the evaluation, values 1.5 or 2.5 points were also allowed. This part of research followed the tenets of the Declaration of Helsinki promulgated in 1964 and was approved by the 
Experimentation Committee of the UCT Prague, which issued informed consent.

\subsection{Statistical analysis}

The scatter of the data was first described by ANOVA (Tukey HSD test, $\mathrm{p}<0.05$ ) using Statistica 13.0 software (StatSoft Inc., USA). Secondly, correlation analysis was calculated between flour features (analytical parameters, rheological tests) and bread quality attributes. Multivariate analysis by principal components (PCA) was conducted for 14 representative parameters, selected on basis of the correlation matrix as well as the PCA results of the complete dataset. For ANOVA and PCA, the factors considered were composite flour base (wheat, wheat-barley, wheat-barley-chestnut/acorn) and enhancement level of non-traditional plant material $(0,5 / 10$ chestnut/acorn, BF30, BF30+5/10 chestnut/acorn).

\section{$3 \quad$ Results and Discussions}

\subsection{Effects of non-traditional plant materials on properties of wheat polysaccharides}

\section{Analytical tests}

According to the TDF contents in the nontraditional materials tested, the amount of dietary fibre increased in composite flours up to twice that in wheat flour alone, mainly by addition of acorn flour (from $3.18 \%$ for WF2 to 7.29 and $7.58 \%$, samples $\mathrm{WF} 2+10 \mathrm{~A}$ and $\mathrm{WF} 2 \mathrm{BF}+10 \mathrm{~A}$; Table 1). When both WF standards were compared, there was a clear difference shown in the Falling number test; it reflected diverse weather conditions during two consecutive harvest years. For the barley flour sample, the value reached about half that level, signifying higher amylase activity and/or a higher rate of damaged starch. Mechanically, physically or enzymatically damaged starch is more accessible to amylases, which contributes to lowering of the value of the Falling number. Between WF1BF and WF2BF premixes, a significant drop was observed in the latter case (Falling numbers 304 and
$168 \mathrm{~s})$ compared to values of 420 and $341 \mathrm{~s}$ for WF1 and WF2, respectively (Table 1).

\section{Pasting behaviour}

For WF controls and the 10 flour composites, differences in amylograph viscosity maxima corresponded with level of Falling number $(r=0.92$, $p<0.001$; data not shown). Besides amylograph maximum viscosity, partial differentiation of the flour composites was obtained at the temperature corresponding to this maximum. Table 1 shows that there was a lesser influence of chestnut flour and strong one of acorn and barley flour. A negative influence of chestnut flour confirmed results by Hegazy et al. (2014) using the RVA test - the viscosity for wheat-chestnut flour 90:10 (w/w) was clearly lower than for wheat control (2036 vs. $2651 \mathrm{mPa} . \mathrm{s}$; decrease ca $23 \%$ ). Conversely, as expected, higher TDF content due to additions of acorn flour caused an increase of the maximal viscosity that exceeded the amylograph technical limit of 1000 Brabender units (BU). In combination with BF, high amylase activity in the alternative cereal flour suppressed the thickening effect of the acorn flour. For wheat-barley-chestnut composites, it seemed that chestnut flour partially buffered the effect of BF. Contrary to our results, direct comparison of pasting of the chestnut and the acorn starches conducted Yoo, Lee, Kim, and Shin (2012) by using of the RVA proof, showed lower peak viscosity for the acorn starch than chestnut starch (4874 mPa.s against $5640 \mathrm{mPa} . \mathrm{s}$, respectively). For acorn starch, these authors determined that this was caused by the smaller size of starch granules, slightly higher total amylose content as well as a weaker resistance to swelling (features swelling power and solubility at $80^{\circ} \mathrm{C}$ ).

\subsection{Effect of non-traditional plant materials on properties of wheat proteins}

\section{Analytical tests}

Baking quality of proteins was satisfactory for both wheat controls - the demanded minimum in praxis is $35 \mathrm{~mL}$. Additions of all non-traditional 
materials induced predictable decrease of sediment volumes during the Zeleny test - the greatest drop was observed for 5 or $10 \%$ of chestnut flour. The combination of barley and especially acorn flour reduced the technological quality of composite flour by approximately one half (Table 2). Reason for this difference may have lain in the different granulation of the alternative materials - chestnut flour appearance was obviously smoother (like a wheat flour) compared to the roughly milled acorn one. On the contrary, BF was produced in industrial mill and its granulation was comparable to wheat flour.

\section{Viscous and elastic behaviour}

Two principal properties of wheat proteins are elasticity and extensibility, expressed as their ratio. For bakery products, the extensigraph elasticity should be 2 or 2.5-times higher than the extensibility; optima of the parameters lie in ranges $450-600 \mathrm{BU}$ and $140-170 \mathrm{~mm}$, respectively. In addition, extensigraph energy taken as area under the curve gives a complex overview of flour technological quality (Př́hoda \& Hrušková, 2017); its empirical minimum is 100 $\mathrm{cm}^{2}$ (Kovaříková \& Netolická, 2011). With respect to the present work, both wheat flour controls WF1 and WF2 fulfilled the demand for good technological quality (the ratios 2.03 and 2.81, the energies 139 and $115 \mathrm{~cm}^{2}$, respectively; Table 2). In our results, baking quality of WF1 could be considered as better than WF2.

Both chestnut and acorn flour added alone $(\mathrm{WF} 1+\mathrm{C}, \mathrm{WF} 2+\mathrm{A})$ noticeably increased the energy level. The shape of the curves, i.e. dough machinability, were affected by enhancement level - the elasticity-to-extensibility ratios rose by about twice and three-times, respectively (Table 2). It could be supposed that non-gluten chestnut and acorn proteins (albumins) first supported the dough extensibility and secondly the elasticity, too. In combination with barley flour, the influence of these alternative plant materials was obvious - the BF proteins released in the non-fermented dough caused it to be more elastic and with lower tensile strength. Changes in the shape of the recorded curves were reflected in extensigraph energy - flour composites based on the stronger WF1 were negatively influenced by a larger extent. For the wheat-barley-acorn counterparts, acorn fibre supported dough elasticity, i.e. it showed a certain potential to correct such quality loss. On the other hand, as the trend registered in the plot attests, there was a stepwise decline in dough handling properties - the higher the wheat flour replacement rate, the greater the increase in extensigraph ratio (up to 14.5 and 11.1 for samples WF1B+10C and $\mathrm{WF} 2 \mathrm{~B}+10 \mathrm{~A}$, respectively). Gonzaga, Batista, Guiné, and Correia (2015) tested wheat-acorn blends mixed in ratios of 90:10 and 85:15 (w/w), comparing flour from two Spanish wheat varieties Cerealis and Ceres. Acorn flour was prepared on a laboratory scale with grain size of less than 1.0 $\mathrm{mm}$. As we found, these authors confirmed the clear-cut rise in the extensigraph ratio according to acorn flour ratio and dough resting time.

\subsection{Effect of non-traditional plant materials on wheat dough during kneading}

For both wheat dough controls, behaviour during kneading was closer than indicated the Zeleny test - the WF2 sample had a little shorter dough development time but about $50 \%$ longer dough stability. Water absorption values of 67.7 and $65.1 \%$ as well as dough softening degrees of 50 and 40 BU could be considered as comparable and satisfactory for enhancement by nontraditional plant materials. With increasing portion of chestnut flour, water absorption of the composites tended to decrease, while dough development was somewhat slowed (time was prolonged) and degree of dough softening slightly increased (Table 3). Hegazy et al. (2014) arrived at different results, owing to differences in technological quality of WF1/WF2 and Egyptian wheat flour - $10 \%$ replacement by chestnut flour improved dough rheological properties (e.g. water absorption had been increased from $56.5 \%$ to $60 \%$, and stability was shortened from $9.0 \mathrm{~min}$ to $7.5 \mathrm{~min}$ ). The authors characterised their base material by protein content about 2 percent points lower $(9.80 \%)$ and with approximately half dough development time $(1.5 \mathrm{~min})$ the Egyptian sample had weaker baking quality than both our controls. 
Dough \& Bread Quality from Wheat-Acorn/Chestnut Flours $\mid 47$

Table 2: Barley, chestnut and acorn flour influence on technological quality of proteins and extensigraph parameters of wheat flour

\begin{tabular}{|c|c|c|c|}
\hline \multirow[b]{2}{*}{ Flour, flour composite } & \multirow{2}{*}{$\begin{array}{c}\text { Analytics } \\
\text { Zeleny value } \\
(\mathrm{mL})\end{array}$} & \multicolumn{2}{|c|}{ Extensigraph test } \\
\hline & & $\begin{array}{l}\text { Ratio* } \\
\text { (1) }\end{array}$ & $\begin{array}{c}\text { Energy* } \\
\left(\mathrm{cm}^{2}\right)\end{array}$ \\
\hline WF1 & $50 \mathrm{~g}$ & 2.03 & $139.5 \mathrm{~cd}$ \\
\hline WF2 & 38 ef & $2.81 \quad \mathrm{~b}$ & $115.3 \mathrm{bc}$ \\
\hline $\mathrm{BF}$ & $22 \quad \mathrm{a}$ & $n . d$. & n.d. \\
\hline WF1BF & $31 \mathrm{~cd}$ & $6.50 \mathrm{e}$ & $113.7 \quad b c$ \\
\hline WF2BF & $27 \quad \mathrm{abc}$ & $4.78 \mathrm{~d}$ & 64.8 \\
\hline $\mathrm{WF} 1+5 \mathrm{C}$ & $40 \mathrm{f}$ & $3.96 \mathrm{c}$ & $148.1 \mathrm{~cd}$ \\
\hline WF1+10C & $39 \mathrm{f}$ & $5.28 \mathrm{~d}$ & 146.2 \\
\hline $\mathrm{WF} 2+5 \mathrm{~A}$ & 34 de & $3.88 \quad \mathrm{c}$ & 135.9 \\
\hline $\mathrm{WF} 2+10 \mathrm{~A}$ & $31 \mathrm{~cd}$ & $6.42 \mathrm{e}$ & 156.2 \\
\hline $\mathrm{WF} 1 \mathrm{BF}+5 \mathrm{C}$ & 29 bc & $11.90 \mathrm{~g}$ & 87.2 \\
\hline $\mathrm{WF} 1 \mathrm{BF}+10 \mathrm{C}$ & $26 \quad a b$ & $14.49 \mathrm{~h}$ & 86.4 \\
\hline $\mathrm{WF} 2 \mathrm{BF}+5 \mathrm{~A}$ & $25 \mathrm{ab}$ & $6.89 \mathrm{e}$ & $89.8 \quad \mathrm{ab}$ \\
\hline $\mathrm{WF} 2 \mathrm{BF}+10 \mathrm{~A}$ & $23 \quad \mathrm{a}$ & $11.09 \mathrm{f}$ & $77.0 \quad a b$ \\
\hline Repeatability & 1 & 0.13 & 8 \\
\hline $\begin{array}{l}\text { Number of groups } \\
\text { (of total) }\end{array}$ & $7 / 12 \quad(a-1)$ & $8 / 12 \quad(a-1)$ & $4 / 12 \quad(\mathrm{a}-\mathrm{l})$ \\
\hline Distinguishing rate & $58 \%$ & $67 \%$ & $33 \%$ \\
\hline
\end{tabular}

* - extensigraph parameters determined after $60 \mathrm{~min}$ of dough resting

WF - Wheat flour; WF1BF, WF2BF - wheat-barley flour premix 70:30 wt. \%, respectively; BF, A, C - barley, acorn and chestnut flour, respectively.

a-h - means in columns the same letter were not statistically different $(\mathrm{p}>0.05)$.

Number of groups - number of homogenous groups, statistically differing in their averages, identified by different letters (a-h).

Total number of groups - number of tested samples $(\mathrm{N}=12$; corresponding letters a-1).

Distinguishing rate $(\%)=100$. Number of homogenous groups/Total number of groups $(=12)$

n.d. - not determined.

The farinograph behaviour of the wheat-acorn flour demonstrated a similar course - water amounts rose by about 2 percent points only, dough development time was increased fourtimes and dough stability fell from $11.0 \mathrm{~min}$ to $9.00 \mathrm{~min}$ (Table 3). Farinograph test results for wheat-acorn composites differs according wheat flour base (Gonzaga et al., 2015) - in the case of variety Cerealis, $10 \%$ acorn flour lowers water absorption ( $60.0 \%$ vs. $55.7 \%)$, and but increases it in the case of the Ceres variety $(57.5 \%$ vs. $59.3 \%)$. They also showed that in terms of dough development time, there is a shortening from 4.0 to $2.0 \mathrm{~min}$ in the former and no significant change in the latter. Comparing our own amylograph and farinograph results, acorn polysaccharides are likely to have a better ab- sorption capacity at lower temperatures than they are when heated. This premise confirmed results by Yoo et al. (2012) that, during the cold phase (beginning) of the RVA test, acorn starch demonstrates a higher viscosity than chestnut starch (5594 mPa.s against $4483 \mathrm{mPa} . \mathrm{s}$, respectively). Yoo et al. (2012) proposed that the reasons for this behaviour are to be found in the different lengths of amylose chains and in content of so-called intermediate materials (slightly branched amylopectin with molar mass between amylopectin and amylose). As far as is known, both starch components influence the properties of water suspension in opposite ways - the amylopectin supports starch swelling, while amylose lowers the viscosity. 
48 | Hrušková et al.

Table 3: Barley, chestnut and acorn flour influence on farinograph behaviour of wheat flour

\begin{tabular}{|c|c|c|c|c|c|c|c|c|}
\hline \multirow{2}{*}{$\begin{array}{l}\text { Flour, flour composite } \\
\text { WF1 }\end{array}$} & \multicolumn{2}{|c|}{$\begin{array}{c}\text { Water absorption } \\
(\%)\end{array}$} & \multicolumn{2}{|c|}{$\begin{array}{c}\text { Dough development } \\
\qquad(\min )\end{array}$} & \multicolumn{2}{|c|}{$\begin{array}{c}\text { Dough stability } \\
\text { (min) }\end{array}$} & \multicolumn{2}{|c|}{$\begin{array}{l}\text { MTI } \\
(\mathrm{BU})\end{array}$} \\
\hline & 67.7 & $\mathrm{~cd}$ & 3.75 & $a b$ & 7.50 & $\mathrm{~b}$ & 50 & $a b$ \\
\hline WF2 & 65.1 & $\mathrm{a}$ & 2.75 & $\mathrm{a}$ & 11.00 & d & 40 & $\mathrm{a}$ \\
\hline WF1BF & 70.0 & $\mathrm{e}$ & 10.00 & $\mathrm{f}$ & 17.00 & $\mathrm{e}$ & 30 & $\mathrm{a}$ \\
\hline WF2BF & 68.0 & $\mathrm{~d}$ & 4.50 & $\mathrm{~b}$ & 3.50 & $\mathrm{a}$ & 120 & $\mathrm{e}$ \\
\hline $\mathrm{WF} 2+5 \mathrm{~A}$ & 66.1 & $a b$ & 8.50 & $\mathrm{e}$ & 4.50 & $\mathrm{a}$ & 50 & $\mathrm{ab}$ \\
\hline $\mathrm{WF} 2+10 \mathrm{~A}$ & 67.5 & $\mathrm{~cd}$ & 10.50 & $\mathrm{f}$ & 9.00 & $\mathrm{c}$ & 70 & $\mathrm{bc}$ \\
\hline $\mathrm{WF} 1 \mathrm{BF}+5 \mathrm{C}$ & 68.2 & $\mathrm{~d}$ & 4.00 & $\mathrm{~b}$ & 4.00 & $\mathrm{a}$ & 100 & de \\
\hline $\mathrm{WF} 1 \mathrm{BF}+10 \mathrm{C}$ & 67.5 & $\mathrm{~cd}$ & 4.00 & $\mathrm{~b}$ & 4.00 & $\mathrm{a}$ & 100 & de \\
\hline $\mathrm{WF} 1+5 \mathrm{C}$ & 66.6 & $\mathrm{bc}$ & 8.00 & de & 9.00 & $\mathrm{c}$ & 50 & $a b$ \\
\hline $\mathrm{WF} 1+10 \mathrm{C}$ & 65.5 & $a b$ & 6.50 & $\mathrm{c}$ & 7.50 & $\mathrm{~b}$ & 70 & $\mathrm{bc}$ \\
\hline $\mathrm{WF} 2 \mathrm{BF}+5 \mathrm{~A}$ & 68.3 & $\mathrm{~d}$ & 7.00 & $\mathrm{~cd}$ & 8.00 & $\mathrm{bc}$ & 90 & $\mathrm{~cd}$ \\
\hline $\mathrm{WF} 2 \mathrm{BF}+10 \mathrm{~A}$ & 68.5 & d & 8.25 & $\mathrm{e}$ & 11.00 & d & 50 & $a b$ \\
\hline
\end{tabular}

\begin{tabular}{|c|c|c|c|c|c|c|}
\hline Repeatability & & & & & 0.20 & 0.20 \\
\hline $\begin{array}{l}\text { Number of groups } \\
\text { (of total) }\end{array}$ & $5 / 12$ & $(a-1)$ & $6 / 12$ & $(a-1)$ & $5 / 12$ & $5 / 12 \quad(a-1)$ \\
\hline Distinguishing rate & \multicolumn{2}{|c|}{$42 \%$} & \multicolumn{2}{|c|}{$50 \%$} & $42 \%$ & $42 \%$ \\
\hline
\end{tabular}

MTI - mixing tolerance index (dough softening degree), BU - Brabender unit.

WF - Wheat flour; WF1BF, WF2BF - wheat-barley flour premix 70:30 wt. \%, respectively;

$\mathrm{BF}, \mathrm{A}, \mathrm{C}-$ barley, acorn and chestnut flour, respectively.

a-f - means in columns with the same letter are not statistically different $(p>0.05)$.

Number of groups - number of homogenous groups, statistically differing in their averages, identified by different letters (a-f).

Total number of groups - number of tested samples $(\mathrm{N}=12$; corresponding letters a- 1$)$.

Distinguishing rate $(\%)=100$. Number of homogenous groups/Total number of groups $(=12)$.

\subsection{Effect of non-traditional plant materials on baking test results}

During leavened dough preparation, recipe water additions were evaluated in the ranges 58.0 - $62.5 \%$ and 53.5 - $59.5 \%$ within the chestnut and acorn sample subgroups, respectively (Table 4). For flour composites based on WF1, the initial water amount of $62.5 \%$ decreased as the chestnut content increased (similarly for samples with the WF1BF base), reflecting an increasing portion of sucrose in dough (Moreira, Chenlo, Torres, \& Prieto, 2010). Conversely, Kucerova, Sottnikova, and Nedomova (2013) found increasing recipe water amount during wheat bread preparation that had been enhanced by $1 \%$ and $3 \%$ of bamboo fibre. Bamboo fibre consists approximately from $97 \%$ cellulose, characterised by higher swelling capacity. Within the subgroup with bases of WF2 and WF2BF, a decreasing trend in water amount was observed. This was the reverse pattern compared to the farinograph water absorption. In spite of a significant rise of TDF content (Table 1), bread formula components such as salt, sugar and fat may have restricted the incorporation of water molecules into the coating of protein chains, and so lowered total amounts of water that had to be added.

The quality of the bread samples was differentiated according to absence or presence of $\mathrm{BF}$ in dough recipe (Figure 1; triplicates of WF1 samples numbered 1-3, WF1BF ones 7-9; WF2 samples 4-6, WF2BF ones 10-12). Although chestnut and acorn flour were added in small portions, both materials decreased specific bread volume (Demirkesen et al., 2010) as well as modifying bread shape. Chestnut flour contains fibre characterised by rigid structures (Demirkesen et al., 2010), which limits the expansion of pores in the dough mass during fermentation (Collar, Santos, \& Rosell, 2007). Dall'Asta et al. (2013) even tested 50\% replacement of soft wheat flour by chestnut flour; such product had 


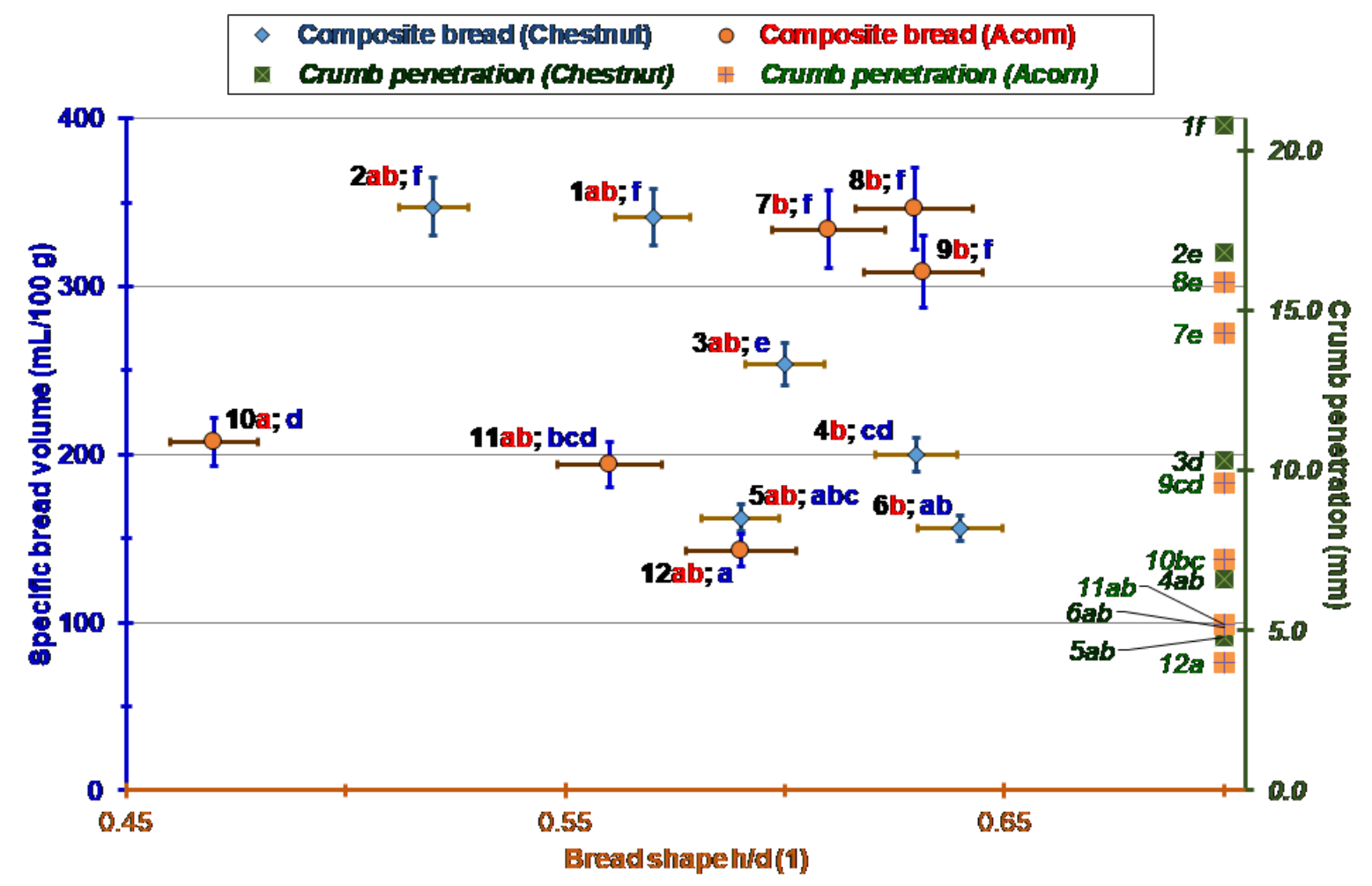

Figure 1: Barley, acorn and chestnut flour influence on wheat bread properties. Samples coding: 1 $\mathrm{WF} 1 ; 2-\mathrm{WF} 1+5 \mathrm{C} ; 3-\mathrm{WF} 1+10 \mathrm{C} ; 4-\mathrm{WF} 1 \mathrm{BF} ; 5-\mathrm{WF} 1 \mathrm{BF}+5 \mathrm{C} ; 6-\mathrm{WF} 1 \mathrm{BF}+10 \mathrm{C}$ (numbers 7-12 similarly within WF2-acorn subset). Variable coding: h/d - height-to-diameter ratio of bread bun. Data variance analysis: bread shape 'a-b' (in red); specific bread volume ' $a-f$ ' (in blue); crumb penetration 'a-f' (in green) - values signed by the same letter are not statistically different $(\mathrm{p}<0.05)$.

a clearly lower specific volume $\left(1.3 \pm 0.2 \mathrm{~cm}^{3} / \mathrm{g}\right.$ vs. $2.8 \pm 0.4 \mathrm{~cm}^{3} / \mathrm{g}$ for wheat control), homogenous porosity with correspondingly higher ratio of pores smaller than $0.049 \mathrm{~mm}^{2}$. We also found that there was a strong relationship between specific bread volume and crumb penetration $(r=$ 0.93, $\mathrm{p}<0.01$; Table 5), with somewhat harder crumb for bread with acorn flour (Table 4).

\subsection{Sensory analysis of bread}

With the sensory profiling, a value of 8 points meant the lowest score, i.e. optimal bread quality in terms of all 8 quality attributes. Replacing $30 \%$ of WF gave a somewhat moister but sticker mouthfeel perhaps due to the presence of $\beta$-glucans ( +0.5 point) and non-typical flavour
$(+0.5$ point $)$ - the bread score reached 9 points. For composite bread variants, the most affected parameters were taste and aroma, chewiness and stickiness. For the most enriched bread, the scores rose 14.5 points (Figure 2), where the maximum 24 points represented unacceptable bread, so this bread was of worse sensory quality by about $41 \%$.

Taste of chestnut flour itself is fruity and sweet, due to the higher content of simple sugars (Dall'Asta et al., 2013). Within WF+chestnut samples, free sugars contributed to darkening of the surface of the final products (Man, Puacean, Muste, Muresan, \& Frâncu, 2012); further worsening was noticed with the development of an elastic, non-crispy crust and denser sticky crumb. The more compact crumb perhaps limited water 
$50 \mid$ Hrušková et al.

Table 4: Baking test results as affected by barley, chestnut and acorn flour additions

\begin{tabular}{lclrlrl}
\hline Flour, flour composite & $\begin{array}{c}\text { Recipe water } \\
\text { addition }\end{array}$ & $\begin{array}{c}\text { Crumb penetration } \\
\text { ( } \mathbf{m m})\end{array}$ & $\begin{array}{c}\text { Bread sensory score } \\
\text { (points) }\end{array}$ \\
\hline WF1 & 62.5 & $\mathrm{i}$ & 20.8 & $\mathrm{f}$ & 8.0 & $\mathrm{a}$ \\
WF2 & 61.0 & $\mathrm{~h}$ & 16.8 & $\mathrm{e}$ & 8.5 & $\mathrm{a}$ \\
WF1BF & 60.5 & gh & 10.3 & $\mathrm{~d}$ & 9.0 & $\mathrm{ab}$ \\
WF2BF & 62.0 & $\mathrm{i}$ & 6.6 & $\mathrm{ab}$ & 10.0 & $\mathrm{~b}$ \\
WF1+5C & 60.0 & fg & 4.8 & $\mathrm{ab}$ & 9.5 & $\mathrm{ab}$ \\
WF1+10C & 58.0 & $\mathrm{c}$ & 5.1 & $\mathrm{ab}$ & 10.0 & $\mathrm{~b}$ \\
WF2+5A & 59.0 & de & 14.3 & $\mathrm{e}$ & 8.0 & $\mathrm{a}$ \\
WF2+10A & 59.5 & ef & 15.9 & $\mathrm{e}$ & 8.0 & $\mathrm{a}$ \\
WF1BF+5C & 58.5 & cd & 9.6 & $\mathrm{~cd}$ & 10.5 & $\mathrm{~b}$ \\
WF1BF+10C & 58.4 & $\mathrm{c}$ & 7.2 & $\mathrm{bc}$ & 9.0 & $\mathrm{ab}$ \\
WF2BF+5A & 56.0 & $\mathrm{~b}$ & 5.2 & $\mathrm{ab}$ & 10.5 & $\mathrm{~b}$ \\
WF2BF+10A & 53.5 & $\mathrm{a}$ & 4.0 & $\mathrm{a}$ & 14.5 & $\mathrm{c}$ \\
\hline
\end{tabular}

\begin{tabular}{|c|c|c|c|c|c|}
\hline Repeatability & 0.1 & \multicolumn{2}{|c|}{0.9} & \multicolumn{2}{|c|}{0.5} \\
\hline $\begin{array}{l}\text { Number of groups } \\
\text { (of total) }\end{array}$ & $9 / 12 \quad(a-1)$ & $6 / 12$ & $(a-1)$ & $3 / 12$ & $(a-1)$ \\
\hline Distinguishing rate & $75 \%$ & \multicolumn{2}{|c|}{$50 \%$} & \multicolumn{2}{|c|}{$25 \%$} \\
\hline
\end{tabular}

WF - Wheat flour; WF1BF, WF2BF - wheat-barley flour premix 70:30 wt. \%, respectively; $\mathrm{BF}, \mathrm{A}, \mathrm{C}-$ barley, acorn and chestnut flour, respectively.

$\mathrm{a}-\mathrm{i}$ - means in columns with the same letter are not statistically different $(\mathrm{p}>0.05)$.

Number of groups - number of homogenous groups, statistically differing in their averages, identified by different letters (a-i).

Total number of groups - number of tested samples $(\mathrm{N}=12$; corresponding letters $\mathrm{a}-\mathrm{l})$

Distinguishing rate $(\%)=100$. Number of homogenous groups/Total number of groups $(=12)$.

evaporation and together with the higher activity of the amylases (lower Falling number) led to a higher occurrence of sticky dextrins than in wheat control. A partial improvement of overall perception brought about by the addition of the chestnut flour when added at over $10 \%$ was due to the increase in sweet taste. In combination with $\mathrm{BF}$, these characteristics were maintained, though mouthfeel stickiness vanished, but typical barley flavour was detected anew. Man et al. (2012) summarised that $10 \%$ of that alternative plant raw material led to the best quality product in terms of taste, odour and colour. These authors found significant and positive changes in bread crumb elasticity, although bread porosity was influenced negatively.

In terms of sensory acceptability, bread attributes got worse for acorn flour additions over $10 \%$ - taste and aroma became woody with a partial acid aftertaste. For WFBF-acorn samples, woody flavour was identified for the sample with $10 \%$ acorn flour in the recipe. During mastication, acorn flour seemed to be milled roughly, so mouthfeel sensation was also "sandy" with some stickiness. One positive effect of acorn flour was the semi-darkening effect on the bread, mainly for recipes containing $10 \%$ or more.

\subsection{Correlation analysis}

The reduced correlation matrix confirmed that bread quality was predetermined by polysaccharides and proteins properties (Table 5). In terms of the analytical and rheological tests, the results of the farinograph proof were less influenced by dough recipe modification - only water absorption influenced specific bread volume negatively $(r=-0.62, p<0.05$; data not shown).

For starch and its constituents, correlation analysis verified a similar relationship between the

\begin{tabular}{l|l|l|l} 
IJFS & April 2019 & Volume 8 & pages 41-57
\end{tabular} 
Dough \& Bread Quality from Wheat-Acorn/Chestnut Flours | 51

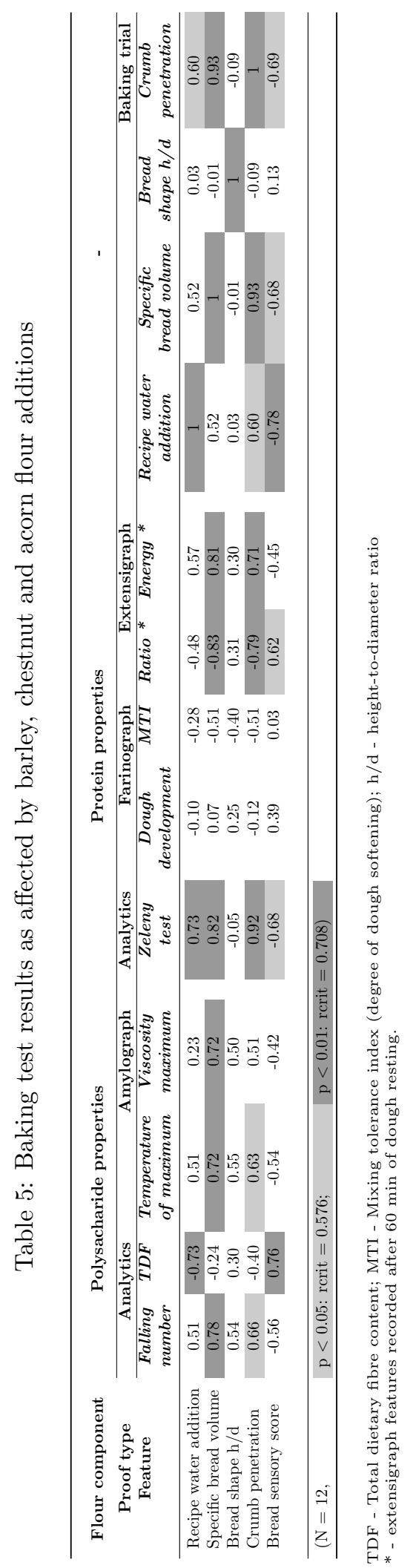

\begin{tabular}{l|l|l|l} 
IJFS & April $2019 \mid$ Volume 8 & pages 41-57
\end{tabular} 
$52 \mid$ Hrušková et al.

\section{$\square W F+(B F+)$ acorn $\quad \square W F+(B F+)$ chestnut}

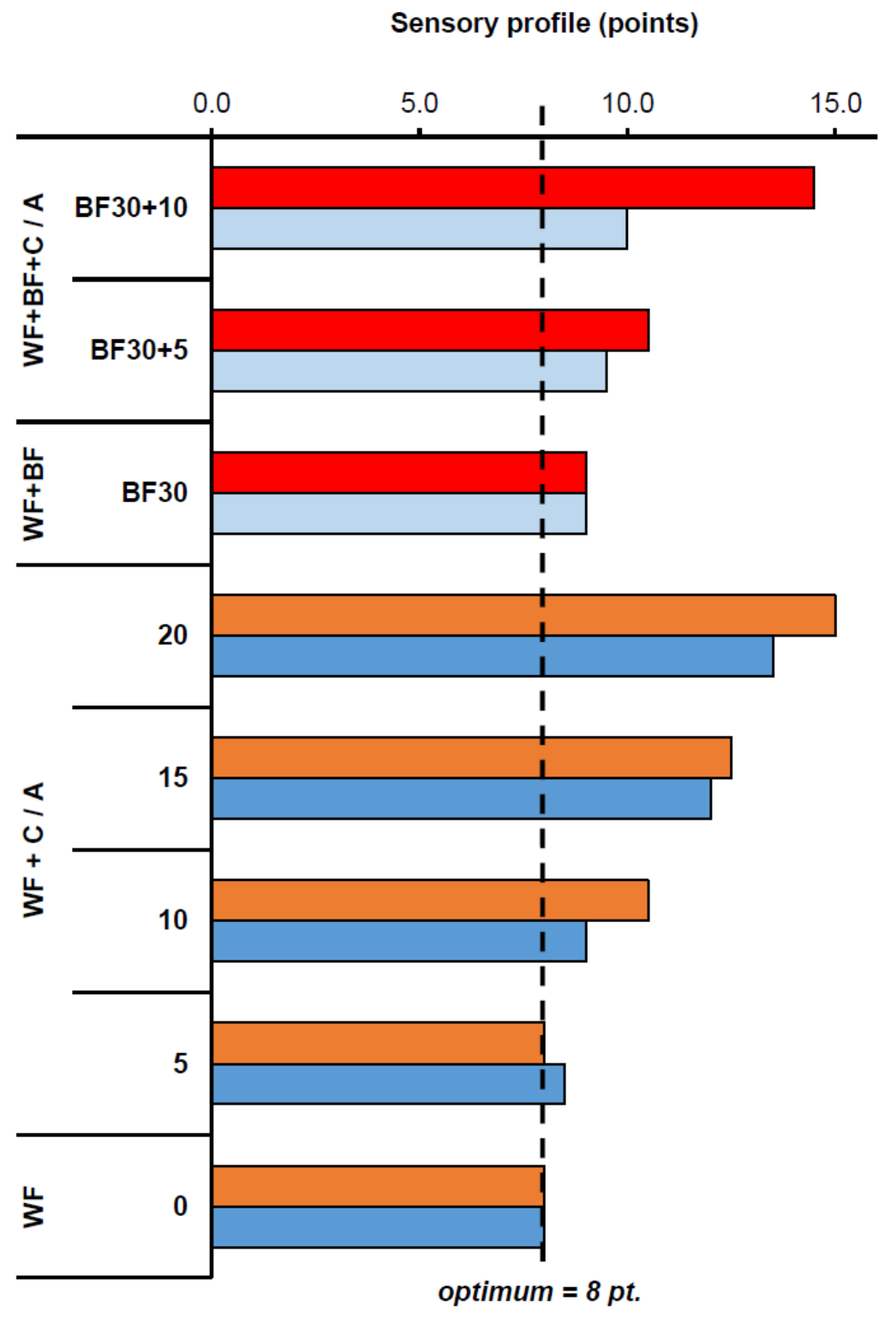

Figure 2: Barley, acorn and chestnut flour influence on sensory profile of wheat bread. 


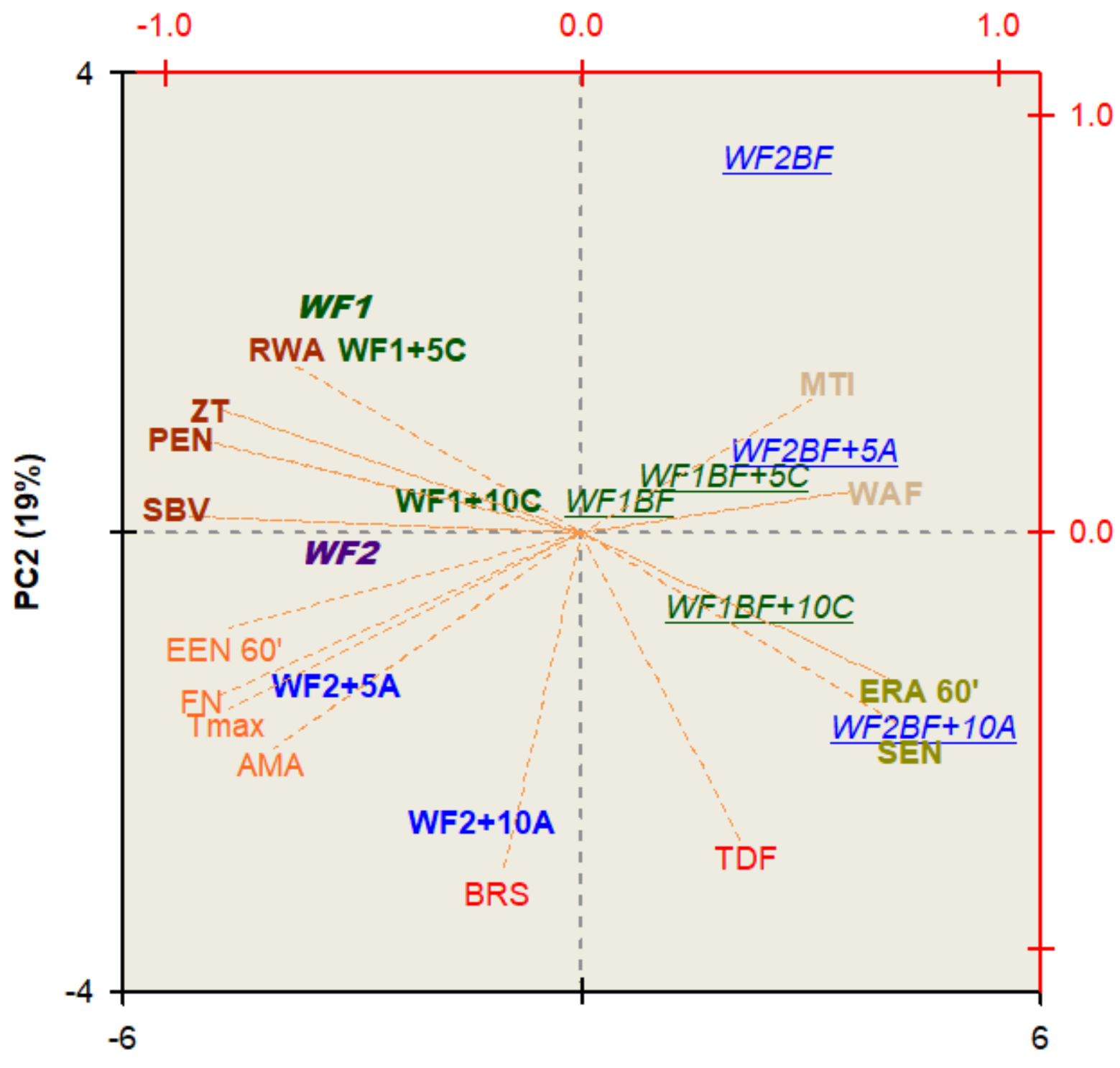

PC1 (55\%)

Figure 3: Principal components (PC) biplot of barley, chestnut and acorn flour influence on wheat flour, dough and bread properties and quality. Samples coding: WF1, WF2 - wheat flour (controls), WF1BF, $\mathrm{WF} 2 \mathrm{BF}$ - wheat-barley flour premixes 70:30 wt. \%; WF1+5C, WF2+10A - flour composites containing $5 \%$ or $10 \%$ of chestnut and acorn, respectively. Variables coding: TDF - total dietary fibre content; FN - Falling number; Zeleny - Zeleny sedimentation value; WAF - farinograph water absorption; MTI - mixing tolerance index (dough softening degree); ERA 60', EEN 60' - extensigraph ratio and energy after 60 min of dough resting; AMA, Tmax - amylograph maximum and proper temperature; RWA recipe water addition; SBV - specific bread volume; BRS - bread shape (height-to-diameter ratio); PEN - crumb penetration; SEN - sensory analysis. 
screening Falling number method, the detailed amylograph pasting test and specific bread volume and crumb penetration (Pearson's $r$ between 0.63 and 0.78). In case of dietary fibre polysaccharides, it seems they played more a important role at lower temperatures during dough mixing (in water absorption) and in bread sensory evaluation $(r=-0.73$ and 0.76 , respectively; $p<0.05)$.

Estimation of baking quality of protein (Zeleny value) in flour composites played a significant role in the prediction of bread quality; with exception of bread shape, it was correlated with four further bread attributes (mostly with calculated $p<0.01$ ). Likewise for extensigraph elasticity-to-extensibility ratio and energy, it was demonstrated that their principal effect was on bun size development (e.g. correlations to specific bread volume, $r=0.82,-0.83$ and 0.81 , respectively; $p<0.01$, Table 5 ).

Finally, specific bread volume could also be estimated on the basis of recipe water addition as well as backwards on the basis of crumb penetration ( $r=0.52 ; r=0.93, p<0.01$, respectively). It supported the premise that bread volume is built on $3 \mathrm{D}$ crumb structure (2D porosity) and its physico-mechanical properties.

In summary, the tighter the relationships between the recorded features, the higher the extent of their explanation by multivariate statistical exploration.

\subsection{Principal component analysis}

In a biplot of loadings and scores, the first two principal components (PC) explained $74 \%$ of data, i.e. $55 \%$ was accounted for $\mathrm{PC} 1$ and $19 \%$ for PC2 (Figure 3). The third PC explained 20\% of variance of the features TDF, extensigraph ratio, recipe water addition and bread shape. In addition, PC4 explained both farinograph features, i.e. for the water absorption and the mixing tolerance index (38\% of trait variability; data not shown). Fourteen representative variables were split into four main groups, demonstrating relationships to bread quality. Specific bread volume and crumb penetration were positively influenced by protein quality (Zeleny value, extensigraph energy, recipe water addition) and negatively on polysaccharide pasting behaviour (Falling number and both amylograph features). It could be presumed that the increasing rate of TDF had an impact on dough rheological properties (water absorption, mixing tolerance index, and extensigraph ratio) and bread characteristics including sensory profile.

As mentioned above, the absence or presence of $\mathrm{BF}$ in dough or bread recipe was crucial to distinguish between the flour composites. Along the PC1 axis, barley flour lowered baking potential of bi-composite mixtures. The PC2 could be associated with addition level of non-traditional plant materials. In this regard, contradictory effects were identified for $10 \%$ of chestnut and $5 \%$ of acorn flour - the former had a worsening effect, but the latter an improving effect (i.e. specific bread volumes 253 and $347 \mathrm{~mL} / 100 \mathrm{~g}$, respectively).

In summary, wheat flour composites with $10 \%$ of chestnut flour and wheat-barley ones with $5 \%$ of chestnut or acorn flour could be recommended for bakery use.

\section{Conclusion}

Enhancement of wheat flour by barley, chestnut and acorn flours contributed to a dietary fibre increase of twice the control level. In flour composites, these non-traditional materials also introduced non-gluten proteins. Such composition changes influenced the technological quality of both polysaccharides and proteins - values of Falling number and Zeleny test were lowered significantly. The effects of chestnut and flour were different, reflecting a wide granulation of the materials. Pasting properties of flour composites were recorded during the amylograph test, and samples could be differentiated according to the temperature of the viscosity maximum. With exception of wheat-acorn samples containing $5 \%$ or $10 \%$ of the acorn flour, viscosity maxima were determined to be about 10-25\% lower in comparison to wheat controls. In this regard, effect of barley flour was stronger than that of chestnut or acorn flour.

Recipe modification also led to changes in dough physico-mechanical properties - non-gluten materials had more influenceon elasticity than ex- 
tensibility of non-fermented dough. Extensigraph elasticity-to-extensibility ratio rose to approximately double for wheat-chestnut, wheatacorn and wheat-barley mixtures. For tricomposite blends, this increase reached a still higher level. Modified polysaccharide and protein properties also significantly influenced rheological behaviour during dough kneading. Water absorption was lessened by additions of chestnut flour, corresponding to the higher portion of sucrose in the flour. Conversely, acorn and barley fibre gradually increased the amount of water necessary to reach the required dough consistency by up to 3 percent points. Dilution of the gluten matrix in the dough led to prolongation of dough development time, and to partial loss of dough resistance to overmixing. Such dough modification caused lower specific bread volumes and variation in the shape of the buns in general; the higher the enhancement level, the lower the bread volume. Lower bread sizes also meant denser crumb, as shown by firmness measurement with the penetrometer. Sensory profiles of bread variants differed primarily on basis of the alternative material added. The wheatbarley and wheat-acorn samples were considered to be less acceptable due to characteristic barley aroma and taste and bitter taste plus acid aftertaste of acorn flour. Wheat-chestnut counterparts had a light sweet taste, but a partial stickiness was identified during mastication. Total sensory score of wheat-barley-acorn bread was clearly worse than the wheat-barley-chestnut one, but in both cases, scores could be categorised as "acceptable with some reservation".

As a compromise between fibre content and final properties of a bakery product, wheat flour composites with $10 \%$ of chestnut flour and wheatbarley ones with $5 \%$ of chestnut or acorn flour could be recommended for practical usage.

\section{Acknowledgements}

The study was conducted under the grant No QI111 B053 of the National Agency of Agricultural Research (NAZV), Czech Republic.

\section{References}

Belcredi, N. B., Ehrenbergerova, J., Belakova, S., \& Vaculova, K. (2009). Barley grain as a source of health-beneficial substances. Czech Journal of Food Sciences, 27, S242S244. 6th Chemical Reactions in Food Conferene 2009, Prague, CZECH REPUBLIC, MAY 13-15, 2009.

Collar, C., Santos, E., \& Rosell, C. M. (2007). Assessment of the rheological profile of fibreenriched bread doughs by response surface methodology. Journal of Food Engineering, 78(3), 820-826. doi:10.1016/j.jfoodeng. 2005.11.026

Correia, P. R., \& Beirao-da-Costa, M. L. (2010). Chestnut and acorn starch properties affected by isolation methods. Starchstarke, 62(8), 421-428. doi:10.1002/star. 201000003

CREA. (2015a). Il Centro di Ricerca Alimenti e Nutrizione. Tabelle di composizione degli alimenti - 3 - Farina di frumento tipo 00. Retrieved from http:// nut. entecra. it / 646 / tabelle_di_composizione \% 20_degli_ alimenti.htmL? idalimento $=000220 \% 5 \mathrm{C} \&$ quant $=100$

CREA. (2015b). Il Centro di Ricerca Alimenti e Nutrizione. Tabelle di composizione degli alimenti - 11 - Farina di castagne. Retrieved from http:/ / nut. entecra.it /646/tabelle di_composizione_degli_\%20alimenti.htmL\% 20? idalimento $=504010 \% 5$ C\&quant $=100$

Dall'Asta, C., Cirlini, M., Morini, E., Rinaldi, M., Ganino, T., \& Chiavaro, E. (2013). Effect of chestnut flour supplementation on physico-chemical properties and volatiles in bread making. Lwt-food Science and Technology, 53(1), 233-239. doi:10.1016/j.lwt. 2013.02 .025

Demirkesen, I., Mert, B., Sumnu, G., \& Sahin, S. (2010). Utilization of chestnut flour in gluten-free bread formulations. Journal of Food Engineering, 101(3), 329-336. doi:10. 1016/j.jfoodeng.2010.07.017

EFSA. (2011). Panel on dietetic products nutrition and allergies - scientific opinion on the substantiation of health claims related to beta-glucans from oats and barley and maintenance of normal blood ldl- 
cholesterol concentrations (id 1236, 1299), increase in satiety leading to a reduction in energy intake (id 851, 852), reduction of post-prandial glycaemic responses (id 821, 824 ), and "digestive function" (id 850) pursuant to article 13(1) of regulation (ec) no 1924/2006. EFSA Journal, 9(6). doi:10 . 2903/j.efsa.2011.2207

Gill, S., Vasanthan, T., Ooraikul, B., \& Rossnagal, B. (2002). Wheat bread quality as influenced by the substitution of waxy and regular barley flours in their native and cooked forms. Journal of Cereal Science, 36(2), 239-251. doi:10.1006/jcrs.2002.0459

Giovannelli, C. (2009). La castagna: Dal bosco alla tavola tradizione ed innovazione the chestnut: From wood to tabel tradition and innovation (Master's thesis, Università degli studi di Padova, Italy). Retrieved from http: / / tesi.cab.unipd.it/21829/1/ TESI_CASATAGNA.pdf

Gonzaga, M., Batista, M., Guiné, R., \& Correia, P. (2015). Development and characterization of wheat breads with acorn flour. In ICEUBI2015-international conference of engineering: Engineering for society.

Hegazy, N. A., Kamil, M. M., Hussein, A. M. S., \& Bareh, G. F. (2014). Chemical and technological properties of improved biscuit by chestnut flour. International Journal of Food Nutritional Science, 3(6), 715. Retrieved from http://www . ijfans . com / Volume \% 203 \% 20Issue \% 206 / 2 . \%20IJFANS\%20A0343-14.pdf

Korus, J., Witczak, M., Ziobro, R., \& Juszczak, L. (2015). The influence of acorn flour on rheological properties of gluten-free dough and physical characteristics of the bread. European Food Research and Technology, 240(6), 1135-1143. doi:10 . 1007 / s00217015-2417-y

Kovaříková, D., \& Netolická, V. (2011). Vzdělávací materiál pro predmět Technologická př́prava. (Quality of cereals for processing in mill. Educational material for subject Technological training) (C. Střední průmyslová škola potravinářská Pardubice Pardubice, Ed.). Retrieved from https://www.spspas.cz/esf-technologickapriprava

Kucerova, J., Sottnikova, V., \& Nedomova, S. (2013). Influence of dietary fibre addition on the rheological and sensory properties of dough and bakery products. Czech Journal of Food Sciences, 31(4), 340-346.

Man, S., Puacean, A., Muste, S., Muresan, C., \& Frâncu, A.-V. (2012). Chestnut flour addition influence on bread quality. Journal of Agroalimentary Processes and Technologies, 18(2), 150-154.

Moreira, R., Chenlo, F., Torres, M. D., \& Prieto, D. M. (2010). Influence of the particle size on the rheological behaviour of chestnut flour doughs. Journal of Food Engineering, 100(2), 270-277. doi:10.1016/j.jfoodeng. 2010.04 .009

Pinna, C. (2013). Acorn bread: A traditional food of the past in sardinia (italy). Journal of Cultural Heritage, 14(3, Supplement), S71-S74. Science and Technology for the Safeguard of Cultural Heritage in the Mediterranean Basin. doi:10.1016/j. culher.2012.11.012

Příhoda, J., \& Hrušková, M. (2017). Hodnocení kvality. Aplikace doporučených přístrojů, metod a interpretace výsledků pro praxi. (Quality evaluation. Application of recommended apparatuses, methods and results interpretation for praxis). In P. S. průmyslových mLýnů (Ed.), (pp. 104-108).

Sabrin, M. (2009). Characterization of acorn meal (Master's thesis, Johnson \& Wales University, USA). Retrieved from https:// getd. libs . uga.edu/pdfs / sabrin_michael_d_ 200908_ms.pdf

Samuel, D. (1997). Cereal foods and nutrition in ancient egypt. Nutrition, 13(6), 579-580. doi:10.1016/S0899-9007(97)00027-0

Silva, S., Costa, E. M., Borges, A., Carvalho, A. P., Monteiro, M. J., \& Pintado, M. M. E. (2016). Nutritional characterization of acorn flour (a traditional component of the mediterranean gastronomical folklore). Journal of Food Measurement and Characterization, 10(3), 584-588. doi:10. 1007/s11694-016-9340-1

Skendi, A., Biliaderis, C. G., Papageorgiou, M., \& Izydorczyk, M. S. (2010). Effects of two 
Dough \& Bread Quality from Wheat-Acorn/Chestnut Flours $\mid 57$

barley beta-glucan isolates on wheat flour dough and bread properties. Food Chemistry, 119(3), 1159-1167. doi:10.1016/j . foodchem.2009.08.030

Švec, I., \& Hrušková, M. (2004). Image data of crumb structure of bread from flour of czech spring wheat cultivars. Czech Journal of Food Sciences, 22(4), 133-142.

Yoo, S.-H., Lee, C.-S., Kim, B.-S., \& Shin, M. (2012). The properties and molecular structures of gusiljatbam starch compared to those of acorn and chestnut starches. Starch, 64(5), 339-347. doi:10.1002/star. 201100104 